\section{Military cutbacks to hit MIT}

\section{Boston}

UNIVERSITIES and research institutes that have come to rely on Department of Defense funds to support research look set to have to rethink their plans and prepare for retrenchment. According to Kenneth A. Smith, vice president for research at the Massachusetts Institute of Technology (MIT), the "promise of glasnost" and continuing federal budget constraints mean that significant cutbacks in military funds can be expected for the 1991 fiscal year.

Earlier this year a report from the Congressional Office of Technology Assessment suggested that a predicted slowing down of military spending will reverse the trends of the Reagan era. In the $1980 \mathrm{~s}$, research and development funding for the Department of Defense grew even faster than the overall defence budget itself, nearly doubling in constant dollars to more than $\$ 37,000$ million.

Military research cutbacks may be good for the country, said Smith, but in the short term they will cause "dislocation and a fair amount of pain". Last month, the Charles Stark Draper Laboratories, an independent military research centre affiliated with MIT until 1973, announced plans for a 10 per cent cutback in personnel. MIT itself is facing similar problems.

As MIT's research budget has grown, the military share has grown even faster, from 11 per cent of "on campus" funding in 1979 to almost 20 per cent $-\$ 45$ million

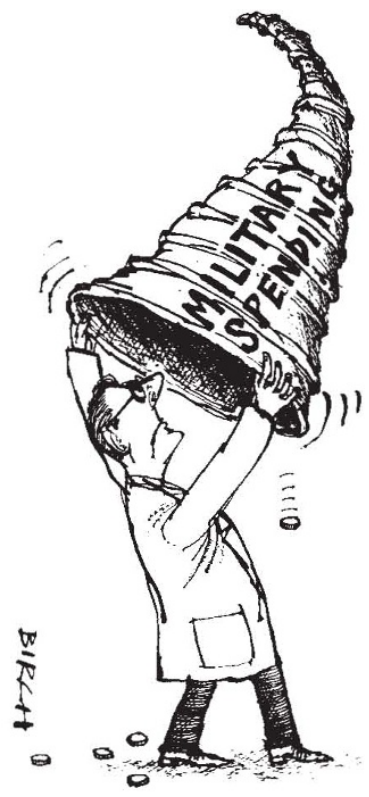

- today. Some research areas at the university, such as the department of aeronautics and astronautics and the artificial intelligence laboratory, receive more than three quarters of their research funds from the Department of Defense.

James Kirtley, a professor of electrical

engineering and a member of an MIT committee that was formed to review military funding at the university, says the impact of cutbacks will be exacerbated because of the tight budgets of other funding agencies. Given the problems that the Department of Energy is having with its weapons production facilities, Kirtley says there are no chances of increases EPIDEMIOLOGY

\section{London}

THE UK Committee on Medical Aspects of Radiation in the Environment (COMARE) last week published a report identifying a "small but statistically significant" increase in the incidence of childhood leukaemia near Britain's two main EPIDEMIOLOGY

\section{Nuclear overhaul}

\section{Washington}

IN an attempt to clean up the damaged image of the US Department of Energy's epidemiological research, the Secretary of Energy, James Watkins, announced last week a complete overhaul of the research programme under the supervision of an independent advisory committee.

Watkins, who assumed office in March, is reacting to criticism that research by the department has been coloured by its primary responsibility for the production of nuclear weapons. Congress is threatening to transfer the research to the Department of Health and Human Services. Watkins denies that there is a conflict of interest, but said at a hearing of the Senate Committee on Governmental Affairs last week that he was "not pleased" with the condition in which he found the programme. "It is understaffed, underfunded and underutilized", he said, and "is buried deep within the bureaucracy."

The plan to revitalize the programme begins with the creation of a committee, whose membership will be announced this week, to advise the department on the budget and to recommend mechanisms for increasing accessibility to the department's epidemiology data, including the creation of a \$36-million data repository (see Nature 340,$251 ; 27$ July 1989). As it will take at least six years to complete the repository, Watkins said he plans to make the data available now. He will announce the members of the committee this week.

Watkins has also asked the National Academy of Sciences to set up a new committee to provide the department with scientific advice on its epidemiology programme, and to control the quality of the research.

Christine McGourty

\title{
Leukaemia increase sets puzzle
}

from that source. And industry will not be taking up the slack, he believes.

But Kosta Tsipis, director of the Program in Science and Technology for International Security, says that the coming reduction in military funds presents an "opportunity for matching an emerging wealth of unusual talent with manifest civilian needs". MIT, he says, should use its decades of experience in both military and civilian research to re-deploy its resources.

Seth Shulman

nuclear-weapons production facilities, the Atomic Weapons Research Establishment near Aldermaston and the Royal Ordnance Factory at Burghfield, both in Berkshire.

The committee found that 41 children were registered with leukaemia compared with an expected number of 28.6 based on the average incidence of leukaemia in England and Wales. All the excess cancers were in children under four years old.

But the committee, chaired by Professor Martin Bobrow, head of paediatrics at Guy's Medical School, said the increase could not be attributed to radioactive discharge from the installations because accidental and authorized emissions were too low. A number of possible explanations were considered, including other potential sources of radiation, but the report concludes that a combination of factors is most probably involved.

In two previous reports, the committee identified increased incidences of childhood leukaemia around the nuclear reprocessing plants at Sellafield and Dounreay. It now says that further research is needed to confirm the findings of all three reports and more information is needed on cancer rates in the rest of the country. The central recommendation is that the geographical distribution of cancer should be studied on a nationwide basis with the aid of an improved registration system. It also recommended that a sample survey of the levels of radionuclides in households around Aldermaston and Burghfield should be carried out.

Leo Kinlen, of the Cancer Research Campaign's epidemiology unit at the University of Edinburgh, believes the results are consistent with the theory that an influx of population can bring an infective agent into a local community which has not built up a resistance to it. This theory is supported, he says, by the clusters of leukaemia found in the isolated populations of Sellafield and Dounreay where the nuclear power plants generated the need for an influx of specialized workers. Although the weapons plants are not in isolated areas, the populations have increased significantly since the $1960 \mathrm{~s}$, says Kinlen.

Ben Webb 